quality education than in the public sector and attracts lowability students. This unfavorable image, coupled with post1995 developments in the public sector, has led to a decrease in the private higher education market share (though the raw numbers continue to rise).

\section{The Privatization of Public Higher Education}

Public education, the only form of higher education in Romania prior to 1990 , had high-quality status. It expanded after 1990, both in the number of institutions (44 to 57, 1989-2003), and in enrollments $(164,507$ to 457,259$)$. The main developments in public higher education have been influenced by a reform process slow paced until 1995, gradually speeding up between 1997 and 2000, and then slowing down again after 2000 .

The reform of the public sector meant a decentralization of the decision-making process and granting academic and financial autonomy. Public universities were allowed to make their own academic decisions, and this led to significant program diversification. Public institutions were allowed to raise extra funds-including tuition fees. Consequently, the number of tuition-fee-paying students greatly increased, doubling the total number of students and bringing the ratio of subsidized to paying students to 50:50 in many public universities. In fact, the process represented a privatization of the public sector that led to increased access to public higher education and thus a larger extent of market coverage by the public sector. Yet, once the public sector was allowed to develop its private side, many public universities have been blamed for excess embracing of economic motivations and for emphasizing quantity over quality. Notwithstanding such criticism, the demand for public higher education has continued to grow. Key aspects of the public privatization and transformation in Romania are also common in other postcommunist countries.

\section{Initially private higher education grabbed a part of the market from a public sector suffering from centralization and inertia.}

\section{Public versus Private Higher Education in the Market}

Initially private higher education grabbed a part of the market from a public sector suffering from centralization and inertia. But lately the public sector's privatization has shifted the market relationship between public and private in two directions. First, many students would rather attend a public university as fee-payers than a private one, to obtain an education with a perceived better quality and a stronger reputation. So the privatization of the public universities takes place at the expense of the private ones. In 2000-2003, a 35 percent increase in total enrollments took place, while the percentage of private higher education total enrollments decreased from 29.5 to 23.3 percent.
The second direction is the increase in the number of feepaying master's programs offered by public universities, in which access is generally free, where the so-called phenomenon of "diploma washing" takes place. This means that graduates of private universities enroll in master's programs at a public university in order to "clean" their initial diplomas, raise the credibility of their studies, and obtain final degrees from a renowned public university.

To conclude, private higher education has started to lose market share lately, as trends on quality diverge: the private sector improves due mainly to accreditation requirements, while the public sector allows its new economic freedom to claim increased market share at the expense of quality. These tendencies do not mean that private-sector quality matches public-sector quality or that private growth has ended. They do, however, suggest a new stage of Romanian private-public marketplace competition, reflecting wider regional tendencies.

\section{Analyzing a Private Revolution: The Work of PROPHE}

\section{Daniel C. Levy}

Daniel C. Levy is director for the Program of Research on Private Higher Education (PROPHE) and Distinguished Professor, at SUNY (University at Albany). Address: School of Education, University at Albany, Albany, NY 12222, USA.E-mail:dlevy@uamail.albany.edu.

$\mathrm{R}_{\mathrm{h}}^{\mathrm{s}}$ eaders of IHE have seen a major flow of entries on private higher education in recent years. This flow reflects what can reasonably be characterized as a "private revolution." Around the world, private higher education has greatly expanded or otherwise gained prominence, often quite suddenly or surprisingly, though usually linked to wider political-economic tendencies of privatization. Complementing and often interacting with the surge in private higher education is the multifaceted privatization of public higher education.

Yet private higher education remains largely a niche field for scholarship. Mainstream higher education literature has shown academia's common sluggishness in identifying and analyzing fast-changing phenomena. On the other hand, news pieces and reports proliferate, showing little or no awareness of private higher education elsewhere or of concepts and data from the still small scholarly literature. Ad hoc impressions and heated and poorly informed polemics usually predominate while vital and multiple policy issues are at stake in country after country.

\section{PROPHE}

Against that background, PROPHE (Program for Research on Private Higher Education) was created, 2000, at the University at Albany, SUNY. It is financed mostly by the Ford Foundation. 
PROPHE is dedicated to building knowledge about private higher education worldwide. Neither pro- nor anti-private, PROPHE does, however, engage major policy issues and dissemination for decision makers and the general public.

PROPHE is a network of scholars in some 20 countries. It additionally includes partner centers and emerging regional centers as well as a network of students working on dissertations on the subject of private higher education. By design, PROPHE is mostly composed of junior scholars.

To see output and activities, see http://www.albany.edu/eps / prophe/. Output includes working papers, edited books, other publications, and conferences. It also includes compilations and analyses of data, relevant laws, and news features from around the world. A large bibliography (2004)-produced in partnership with Boston College's CIHE-provides a guide for scholars and policymakers. CIHE also cooperates by allocating to PROPHE a regular column in IHE.

\section{PROPHE is a network of scholars in some 20 countries. It additionally includes partner cen- ters and emerging regional centers as well as a network of students working on dissertations on the subject of private higher education.}

\section{ENROLLMENTS}

PROPHE's developing database covers institutions, faculty, field of study, diploma or degree levels, geographical concentrations, and the like. Culling just system enrollments from the total picture, we get a quick feel of the breadth and intensity of the private revolution.

No region is unaffected. Postcommunist Eastern and Central Europe has moved from virtually 0 to as high as 20 and 30 percent in some countries. China is now about 10 percent private, and Mongolia and Southeast Asia have private sectors. Major developments likewise characterize South Asia and the Middle East as well. Several Asian countries with longstanding private higher education show large majority enrollments (Japan, Philippines, and South Korea). Latin America's roughly 40 percent average also includes countries with private majorities (Chile, Brazil, and the Dominican Republic). Africa has come recently from near 0 to figures as high as 20 percent in countries like Kenya.

Analysis shows that the private revolution is much clearer and dramatic in developing than developed regions. Western Europe remains the region with the least private higher education, though interesting changes are emerging there, too, and private higher education now has a notable place in New Zealand and Australia. Furthermore, the nature as well as the size of enrollments is changing. U.S. private higher education holds rather steady, around 21 percent, but dramatic is the rise of for-profits as well as a more general commercialization of nonprofit (and even public) institutions. Japan has just begun to experiment with for-profits.

\section{IsSUES For Analysis}

So the private higher education revolution is not about numbers alone. It is also about profound changes within the sector. A related subject for study is how private higher education fits into broader higher education reform trends internationally, from finance to governance, accountability, autonomy, accreditation, and much more. Beyond "fit" is even the question of leadership: how, how much, and where does private higher education lead major higher education changes?

At the same time, analysis shows that private higher education is far from just one phenomenon. It varies greatly across regions, across countries, and even within countries. Subsectoral variation is huge, as the for-profit versus nonprofit matter shows and as differences among religious/cultural, academic, and commercial subsectors further show. Without doubt, the most extensive and profound revolution has been occurring on the commercial side.

Analysis must be intersectoral as well. PROPHE looks at changing degrees and at the distinctiveness and similarities between the private and public sector. Comparisons include private subsectors versus public subsectors. Additional issues, often crucial for policy analysis as well, concern intersectoral cooperation and conflict. Cooperation has in many countries gone as far as formal private institution partnerships with public institutions.

PROPHE thus has an active and expanding research agenda. Yet it is a daunting challenge to try to document and analyze the private higher education revolution that is sweeping so much of the world.

\section{University-Industry Partnerships Reconsidered: MIT, Cambridge, and Tokyo}

\section{Sachi Hatakenaka}

Sachi Hatakenaka is an independent researcher and consultant on higher education policy and organizational management, and is currently a Research Fellow at the Industrial Performance Center at MIT. E-mail: sachi@alum.mit.edu.

$\mathrm{U}$ niversity-industry partnerships have been a hot topic for universities, industry, and governments alike. That universities should play an economic role is becoming a dominant view globally, though everyone interprets the concept differently. Universities tend to see relationships with industry as new revenue sources. Industry focuses on narrow benefits such as student recruitment or specific technical solutions. Governments, on the other hand, want universities to generate new industries or to stimulate existing ones and often see spinoffs or licensed patents as an obvious metric of success.

These respective wishes have often led to some tensions. 